\title{
A unique subtidal vermetid reef formation in a nuclear power plant discharge area at Ilha Grande Bay (southwestern Atlantic Ocean)
}

\author{
André Breves $^{1 *}$, Fernando Coreixas Moraes ${ }^{2}$, Alexandre Dias Pimenta ${ }^{3}$ and Andrea Oliveira Ribeiro Junqueira ${ }^{1}$
}

\begin{abstract}
Background: The reef-building vermetid Petaloconchus varians is a dominant species on the intertidal zone of rocky shores at llha Grande Bay (Rio de Janeiro State, Brazil).

Methods: On August 2010, subtidal vermetid reefs were collected in the nuclear power plant discharge area at Ilha Grande Bay. The characteristics of the subtidal reefs were investigated, being described their formation, density and range extension.

Results: These are monospecific reefs formed by dense clusters of $P$. varians, developing mainly by peripheral growth on the rims of most of the bottom rocks resembling "microatolls". The reefs were recorded spreading over about $1,000 \mathrm{~m}^{2}$, restricted to the nuclear power plant discharge area, under continuous influence of waterflow currents $\left(30 \mathrm{~cm} \cdot \mathrm{s}^{-1}\right)$, high temperature $\left(>36^{\circ} \mathrm{C}\right)$ and chlorine inputs.

Conclusion: It is a unique subtidal $P$. varians reef formation in the nuclear power plant discharge area at llha Grande Bay, with unprecedented records in the Brazilian coast.
\end{abstract}

Keywords: Brazilian coast, Microatoll, Nuclear Plants, Petaloconchus varians, Vermetidae

\section{Background}

Vermetidae is a family of unusual sessile marine gastropods found in warm-temperate to tropical seas (Morton, 1951; Keen, 1961). They have a great morphological plasticity characterized by irregular shells growth, adapted to hard substrata (Savazzi, 1996; Schiaparelli \& Cattaneo-Vietti, 1999). One of the most interesting and significant aspects of the vermetids is related to their role as reef-building (Vescogni et al., 2008) usually encrusting intertidal rocks and forming massive reefs (Azzopardi \& Schembri 1997).

Peculiar vermetid reefs composed by Dendropoma and Vermetus were reported by Safriel (1974) on the coast of Israel in the Mediterranean and Bermuda in the Atlantic. In both cases the reefs were described as intertidal formations resembling miniature atolls ("microatolls" and

\footnotetext{
* Correspondence: abrevesramos@gmail.com

${ }^{1}$ Instituto de Biologia, UFRJ, Rio de Janeiro, Brazil

Full list of author information is available at the end of the article
}

locally called "boilers"), usually circular with raised, overhanging rims higher at the seaward side. They enclose a shallow basin with a flat bottom in Israel and a deep cup-shaped hollow in Bermuda (Safriel, 1974). On the other hand, according to Safriel (1975), the similarity of the Israel and Bermuda reefs is only a superficial one. Whereas the Israeli reefs are rocky ledges only incrusted and thus maintained by the vermetids, the Bermuda "microatolls" are genuine organic reefs (Safriel, 1975).

Vermetids can be found in almost all the Brazilian coast and oceanic islands usually in association with coralline algae (Laborel \& Kempf, 1965; Laborel, 1977; SoaresGomes et al., 2001). A recent study of Spotorno et al. (2012) summarized the occurrences of all Vermetidae taxa recorded from Brazil, broadening the knowledge of the group and their geographical distribution.

One of the most common reef-building vermetid species found along the Brazilian coast is Petaloconchus varians (d'Orbigny, 1841), registered in a quite long time 
until current days (Laborel \& Kempf, 1965; Spotorno et al., 2012) and its distribution ranges is the Western Atlantic Ocean (Bieler, 2015). Petaloconchus varians reefs are found in several rocky shores in the intertidal zone in Brazil (Spotorno et al., 2012). This filter feeder species has a very variable growing, normally forming dense colonies with 100-200 mm in length (Soares et al., 2011; Spotorno et al., 2012).

On the southernmost region of Rio de Janeiro State (Brazil), P. varians is dominant on intertidal rocky shores of many locations at Ilha Grande Bay (Breves-Ramos et al., 2010), forming a well-developed and complex reef. Herein we record in this bay a unique $P$. varians subtidal reef formation at the discharge area of the nuclear power plants, verifying their range extension and density and also analyzing conditions that contribute to their shape.

\section{Methods}

The study was carried out in the Brazilian nuclear power plants (Central Nuclear Almirante Álvaro Alberto CNAAA) effluent discharge area, located at Piraquara de Fora cove, in Ilha Grande Bay $\left(23^{\circ} 00^{\prime} 44.06^{\prime \prime} \mathrm{S} / 44^{\circ} 26^{\prime}\right.$ $48.27^{\prime \prime} \mathrm{W}$ ). The local climate is tropical wet (Silva et al. 1989) and the surface seawater temperature in the bay is frequently warm, normally ranging from 24.4 to $28.4{ }^{\circ} \mathrm{C}$ (Creed et al. 2007).

The power plants cooling system demands $120 \mathrm{~m}^{3} . \mathrm{s}^{-1}$ of the open sea-water and the effluent discharge causes an increase in the water temperature of Piraquara de Fora cove. The mean temperature of the seawater in this area ranges from $29.5^{\circ} \mathrm{C}$ in winter to $36.5^{\circ} \mathrm{C}$ in summer (Teixeira et al., 2009) and the thermal plume reaches an area of approximately $3,7 \mathrm{~km}^{2}$ (Lucca et al., 2005). Other local impacts caused by the power plants include chlorine inputs $\left(0.04 \mathrm{mg} . \mathrm{L}^{-1}\right)$ and outflow currents $\left(30 \mathrm{~cm} \cdot \mathrm{s}^{-1}\right)$ that may influence the community density and richness in this area (Teixeira et al., 2009). Moreover, this area was heavily affected by continental landslides during strong rains in the
80' (Villena et al., 2005; Soares, 2006). Consequently, several of large boulders fell into the sea bottom providing new substrates that were colonized by benthic organisms (Teixeira et al., 2012).

On August 2010, during the winter period, we investigated the subtidal vermetid reefs in the discharge area of the power plants. The reefs were photographed underwater with a digital camera and samples were manually collected, stored in labeled plastic bags, fixed and preserved in $70 \%$ ethanol. In the laboratory the density was estimated through photos by counting the shell aperture of all living individuals. They were identified and housed in the Mollusks Collection at the Museu Nacional (UFRJ), Rio de Janeiro, Brazil [Lot MNRJ18,786].

\section{Results and discussion}

Subtidal vermetids reefs were recorded in the nuclear power plants discharge area, fouling tens of boulders ( 1 to $6 \mathrm{~m}$ in diameter) in the sea bottom between one and six meters depth. This vermetid reefs are formed by clusters of living individuals cemented around a peripheric area of the rocks from the bottom to near the top, which is normally inhabited by unidentified algae (Fig. 1a, b). In some rocks, because of their high development, vermetids also inhabited the top.

Such features resemble the "microatolls" described by Safriel $(1974,1975)$ for Bermuda and Israel. However, there are differences concerning the species composition, origin, depth, water temperature and others. The vermetid reefs recorded in the present paper are monospecific, formed by clusters of $P$. varians incrusted on subtidal rocks, in an area with unusual high temperature. According to Safriel (1974), the Shikmona reefs from Israel are situated on the intertidal and made of limestone encrusted by vermetids. The limestone relief is leveled off and surrounded by an elevated rim, covered by a crust of Dendropoma petraeum, while the basin is covered by a crust of Vermetus triquetrus. In the Bermuda "microatolls", Dendropoma irregulare provides the bulk of their crust, growing all over the reefs surface.

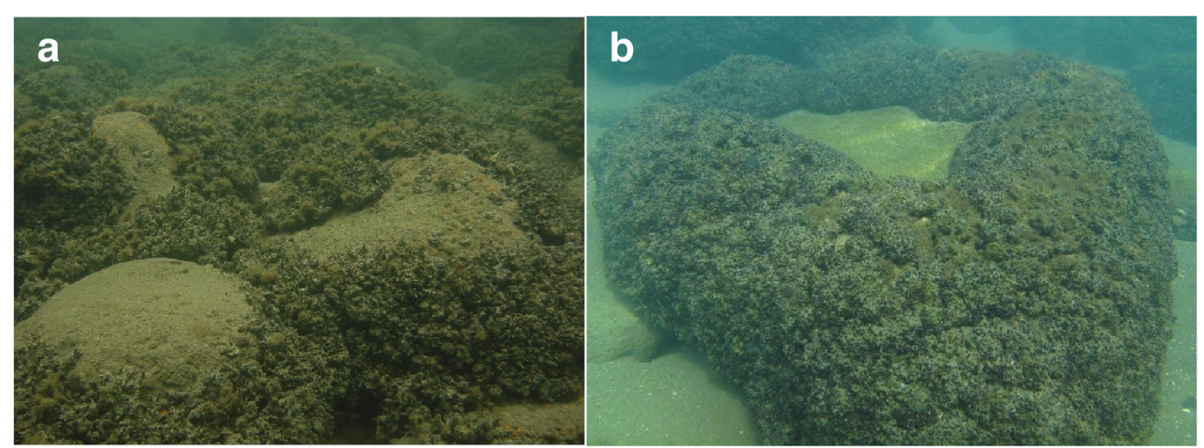

Fig. 1 a-b: Subtidal Petaloconchus varians reefs resembling "microatolls" in the nuclear power plant discharge area at Ilha Grande Bay (Rio de Janeiro, Brazil) 
Moreover, the reefs are made of biogenic material, at least to the depth of $5 \mathrm{~m}$ into the reefs (Safriel, 1974). Considering the sea-surface temperatures, there is similarity between Israel and Bermuda, since both are located on the same latitude. In the coldest month the mean temperature in Bermuda, being $19{ }^{\circ} \mathrm{C}$, is higher than in Israel, while summer temperatures in both places are the same (Safriel, 1974).

The highest density of the subtidal $P$. varians were around 100,000 ind. $\mathrm{m}^{-2}$ and similar values were found on the intertidal in the same area (Breves-Ramos, 2012). On the other hand, values up to 300,000 ind. $\mathrm{m}^{-2}$ were found on intertidal rocky shores in the same bay around $8 \mathrm{~km}$ of the impacted area (Breves-Ramos, 2012). The effluent of the nuclear power plant seems to impact their density, since it may cause the decrease in benthic cover (Teixeira et al., 2009) and lack of macro-organisms (Mayer-Pinto et al., 2012).

Mainly high chlorine input and high temperatures seem to be responsible for the drastic low diversity in this area creating a desert landscape in the sea bottom. This condition, added to lack of competitors, facilitate the intertidal dominant species $P$. varians to attach free spaces on subtidal rocks in this area. Furthermore, in general vermetids are known for their high tolerance to adverse environmental conditions (Schiaparelli \& Cattaneo-Vietti 1999; Strathmann \& Strathmann 2006), with a great ability to attach to different artificial substrates (Schiaparelli et al., 2003). Besides vermetids few organisms are found; the sea urchin Lytechinus variegatus the sponge Hymeniacidon heliophila and the ascidian Phallusia nigra. The geniculate calcareous algae Jania sp., the brown algae Sargassum spp. and the soft coral Palythoa caribaeorum can also be found (Teixeira et al., 2012).

Vermetids feed on particles, such as microscopic plants and animals and detritus. For predominantly mucous feeders, the mucous trap hangs undisturbed while gathering food material (Al Barash \& Zenziper 1985). Hydrodynamics might be affecting these populations, since according to Schiaparelli \& Cattaneo-Vietti (1999), vermetids are warm-water sessile gastropods capable of building upright tubes (feeding tubes) to take advantage of the water flow, as exploratory tubes. In a power plant channel at Planta Centro in Puerto Cabello, Venezuela, dense mass aggregation of $P$. varians lives in the intertidal, with a permanent flow of water (Weinberger et al. 2010).

These subtidal $P$. varians reefs were recorded spreading over about $1,000 \mathrm{~m}^{2}$ into the Piraquara de Fora cove (Fig. 2), restricted to the nuclear power plant discharge area, under continuous influence of strong currents and high temperature. There is no other subtidal $P$. varians reefs in anywhere else in Ilha Grande Bay.

\section{Conclusions}

This is a unique vermetid reef formation found in Ilha Grande Bay, especially because of its peculiar characteristics and presence in the subtidal zone of the nuclear power plant effluent discharge area. It is also a reef formation with unprecedented records on the Brazilian coast

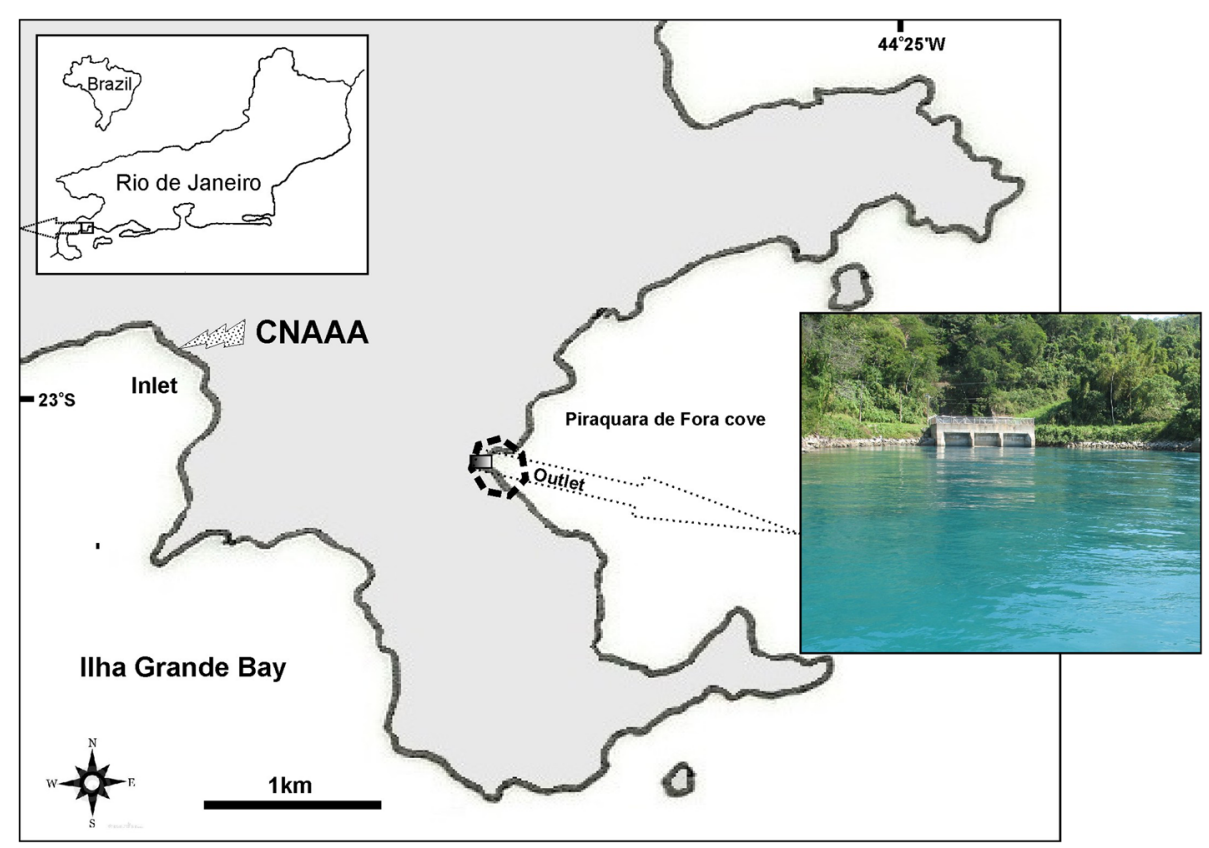

Fig. 2 Location of the Brazilian Nuclear Power Plant (CNAAA) and the range extension of subtidal P. varians reefs (dashed polygon) in the Piraquara de Fora cove (Ilha Grande Bay, Rio de Janeiro, Brazil). 


\section{Abbreviation}

UFRJ, Universidade Federal do Rio de Janeiro

\section{Acknowledgements}

We gratefully thank Brazilian National Counsel of Technological and Scientific Development (CNPq) for the doctoral scholarship (Proc.140668/2011-0) to the first author; Eletronuclear Eletrobrás for logistic support and Instituto Chico Mendes de Conservação da Biodiversidade (ICMBio) for research license SISBio n¹7982-2. We also thank Maurício Fernandes for helping in field work.

\section{Authors' contributions}

$A B$ carried out fieldwork, took the photograph from Fig. 2, identified organisms and wrote the manuscript with contributions from all other authors. FCM carried out fieldwork and took the photographs from Fig. 1; ADP carried out fieldwork and identified organisms. All authors read and approved the final manuscript.

\section{Competing interests}

The authors declare that they have no competing interests.

\section{Author details}

${ }^{1}$ Instituto de Biologia, UFRJ, Rio de Janeiro, Brazil. ${ }^{2}$ Jardim Botânico do Rio de Janeiro, Rio de Janeiro, Brazil. ${ }^{3}$ Departamento de Invertebrados, Museu Nacional, UFRJ, Rio de Janeiro, Brazil.

Received: 22 June 2016 Accepted: 23 June 2016

Published online: 25 July 2016

\section{References}

Azzopardi L, Schembri PJ. Vermetid crusts from the Maltese Islands (Central Mediterranean). Mar Life. 1997;7(1-2):7-16.

Al Barash, Zenziper Z. Structural and biological adaptations of Vermetidae (Gastropoda). B Mal. 1985;21(7-9):145-76

Bieler R. Petaloconchus varians (d'Orbigny, 1839). In: World Register of Marine Species. MolluscaBase. 2015. http://www.marinespecies.org/aphia. php? $\mathrm{p}=$ taxdetails\&id=419554. Accessed 02 Dec 2015

Breves-Ramos A. Malacofauna survey and population structure of Isognomon bicolor and Myoforceps aristatus in Petaloconchus varians (Gastropoda: Vermetidae) reefs at Ilha Grande Bay (Rio de Janeiro, Brazil), PhD Thesis. Rio de Janeiro, Brazil: Museu Nacional (UFRJ); 2012

Breves-Ramos A, Pimenta AD, Széchy MTM, Junqueira AOR. Mollusca, Bivalvia, Mytilidae, Myoforceps aristatus (Dillwyn, 1817): distribution and new record localities at Ilha Grande Bay. Brazil Check List. 2010;6:408-9.

Creed JC, Pires DC, Figueiredo MA. Biodiversidade marinha da Baía da Ilha Grande. 1st ed. Brasília: MMA/SBF; 2007

Keen AM. A proposed reclassification of the gastropod family Vermetidae. Bull Brit Mus Nat Hist Zool. 1961;7:183-213.

Laborel J, Kempf M. Formações de vermetos e algas calcarias nas costas do Brasil. Trop Oceanogr. 1965;7/8:33-50.

Laborel J. Are reef-building vermetids disappearing in the South Atlantic? Miami, Florida: Proc Third ICRS University of Miami; 1977. p. 233-7.

Lucca EVD, Bandeira JV, Lorenzzetti JA, Moreira RC, Castro RM, Salim LH, et al. (2005) Using airborne hyperspectral scanner to monitoring the oceanic thermal plume produced by the surface discharge of the cooling water from Angra dos Reis nuclear power plant. Braz J Cartog. 2005;57:48-55.

Mayer-Pinto M, Ignacio BL, Szechy MTM, Viana MS, et al. How much is too little to detect impacts? A case study of a nuclear power plant. Plos One. 2012 7(10):1-8

Morton JE. The structure and adaptations of the New Zealand Vermetidae. T Roy Soc NZ ZOOL. 1951;79:1-19.

Orbigny A. Voyage dans l'Amérique Méridionale (le Brésil, la République de Orientale de l'Uruguay, la République Argentine, la Patagonie, République du Chili, la République de Bolivia, la République de Pérou). Tome 5, Partie 3, Mollusques. Pitois-Levrault. Strasbourg, Paris. Livraison 1841;44-52

Safriel NU. Vermetid gastropods and intertidal reefs in Israel and Bermuda. Science. 1974;186:1113-5

Safriel NU. The Role of Vermetid Gastropods in the Formation of Mediterranean and Atlantic Reefs. Oecologia. 1975;20:85-101.

Savazzi E. Adaptations of vermetid and Siliquariid Gastropods. Palaeontology. 1996:39:157-77
Schiaparelli S, Cattaneo-Vietti R. Functional morphology of vermetid feeding tubes. Lethaia. 1999:32:41-6.

Schiaparelli S, Guidettio P, Cattaneo-Vietti R. Can mineralogical features affect the distribution patterns of sessile gastropods? The Vermetidae case in the Mediterranean Sea. J Mar Biol Assoc UK. 2003;83:1267-8.

Silva SHG, Junqueira AOR, Silva MJM, Zalmon IR, Lavrado HP. Fouling and woodboring communities distribution on the coast of Rio de Janeiro, Brazil. In: Neves C, Magoon OT, editors. Coastlines of Brazil. New York: American Society of Civil Engenier; 1989. p. 95-109.

Soares EP. Characterization of precipitation in the region of Angra dos Reis and its relation with the occurrence of landslides, Master's Thesis. Rio de Janeiro, Brazil: PEC-COPPE, UFRJ; 2006

Soares MO, Meirelles CAO, Lemos VB. Reef bioconstructors of the Rocas Atoll. Equatorial South Atlantic Biotemas. 2011;24(2):37-46.

Soares-Gomes A, Villaça R, Pezzella CAA. Atol das Rocas: ecossistema único no Atlântico Sul. Ciência Hoje. 2001;29(172):32-9.

Spotorno P, Tâmega FTS, Bemvenuti CE. An overview of the recent vermetids (Gastropoda: Vermetidae) from Brazil. Strombus. 2012;19:1-8.

Strathmann MF, Strathmann R. A vermetid gastropod with complex intracapsular cannibalism of nurse eggs and sibling larvae and a high potential for invasion. Pac Sc. 2006;60(1):97-108

Teixeira TP, Neves LM, Araújo FG. Effects of a nuclear power plant thermal discharge on habitat complexity and fish community structure in Iha Grande Bay. Brazil Mar Environ Res. 2009;68:188-95.

Teixeira TP, Neves LM, Araújo FG. Thermal impact of a nuclear power plant in a coastal area in Southeastern Brazil: effects of heating and physical structure on benthic cover and fish communities. Hydrobiologia. 2012;684:161-75.

Vescogni A, Bosellini FR, Reuter M, Brachert TC. Vermetid reefs and their use as palaeobathymetric markers: new insights from the late Miocene of the Mediterranean (Southern Italy, Crete). Palaeogeogr Palaeocl. 2008;267:89-101.

Villena HH, Pereira SD, Ferreira da Silva LC. Influência da dinâmica de correntes no relevo de fundo e na cobertura sedimentar da enseada de Piraquara de Fora, Angra dos Reis - RJ. Bol. Cong. Annals of Congress Associação Brasileira de Estudos do Quaternário. 2005;141:1-6.

Weinberger VP, Miloslavich P, Machordom P. Distribution pattern, reproductive traits, and molecular analysis of two coexisting vermetid gastropods of the genus Petaloconchus: a caribbean endemic and a potential invasive species. Mar Biol. 2010;157:1625-39.

\section{Submit your next manuscript to BioMed Central and we will help you at every step:}

- We accept pre-submission inquiries

- Our selector tool helps you to find the most relevant journal

- We provide round the clock customer support

- Convenient online submission

- Thorough peer review

- Inclusion in PubMed and all major indexing services

- Maximum visibility for your research

Submit your manuscript at www.biomedcentral.com/submit
) Biomed Central 